\title{
Niemann-Pick C1-Like Protein 1
}

National Cancer Institute

\section{Source}

National Cancer Institute. Niemann-Pick C1-Like Protein 1. NCI Thesaurus. Code C74462.

Niemann-Pick C1-like protein 1 (1359 aa, 149 kDa) is encoded by the human NPC1L1 gene. This protein is a multipass transmembrane protein and plays a role in cholesterol and lipid homeostasis. 